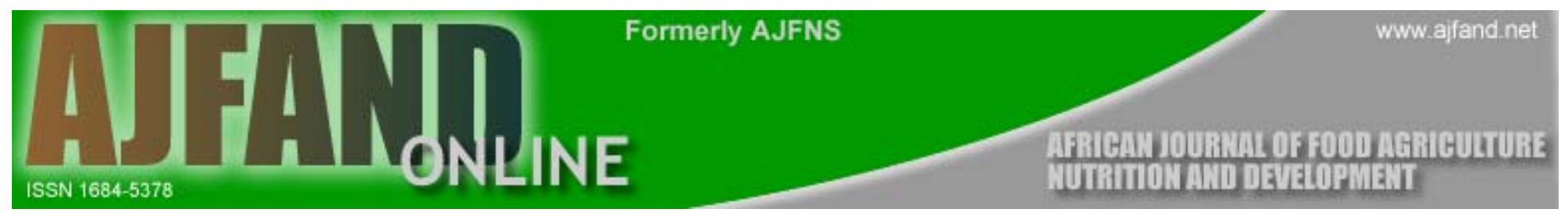

PEER REVIEWED ARTICLE No 1

\title{
A COMPARATIVE STUDY ON THE NUTRITIONAL STATUS OF CHILDREN (6-59 MONTHS) IN A WORLD VISION PROJECT AREA AND A NON-PROJECT AREA IN KATHONZWENI DIVISION, MAKUENI DISTRICT, KENYA
}

\author{
*Macharia $C W^{1}$, Kogi-Makau $W^{2}$ \\ NM Muroki ${ }^{3}$
}

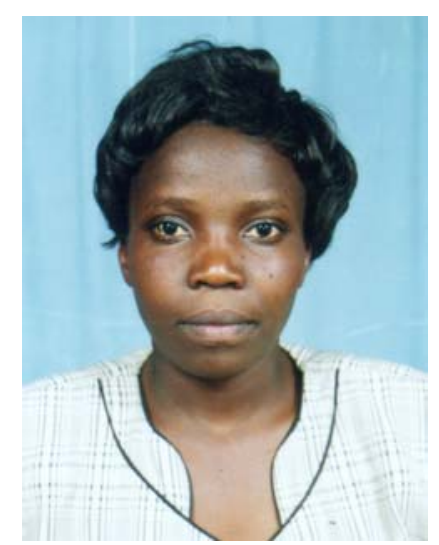

Cathrine Macharia

* Corresponding Author

${ }^{1}$ BA (Anthr), MSc. Email - waleso2002@yahoo.com

${ }^{2} \mathrm{BEd}, \mathrm{MSc}, \mathrm{PhD}$ (Senior Lecturer)

${ }^{3}$ BSc, MSc, PhD, MPS (Associate Professor)

Applied Nutrition Programme, University of Nairobi, P.O. Box 442, Uthiru, Nairobi 


\section{ABSTRACT}

A cross-sectional survey was conducted in Kathonzweni division, Makueni district to assess and compare the nutritional status of children (6-59 months) drawn from households participating in a World Vision project vis-à-vis non-project area. The purpose of the study was to provide region specific data on the nutrition situation in the World Vision Project area and establish whether there is any significant difference from the non-operational area. A total of 320 households, of which 160 were from the World Vision project area each with at least a child aged between 6-59 months were randomly selected. In households with more than one child at this age category, only one child was selected. Structured questionnaires were administered to mothers or to alternative caretakers while anthropometric measurements were taken for all the children in the study households. Statistical package for Social Scientists (SPSS/PC) computer package was used for data entry and analysis. Indices of nutritional status that is weight-for-age, height-for-age and weight-for-height were computed using the Epi-Info programme. The prevalence of stunting in the project area $(46.5 \%)$ was slightly higher than among the non-project area $(\mathbf{4 2 . 1 \% )}$. A significant relationship was found between the children's age and their nutritional status based on the prevalence of wasting and of underweight $(p<0.01)$ while nutritional status, based on stunting, was significantly associated with birth order. Overall, there was no significant difference in prevalence of stunting, wasting and underweight between the world vision project area and nonproject area. However, the prevalence of stunting and underweight was higher than the national levels. It is, therefore, concluded that chronic malnutrition is a problem in the study area and age is an important determining factor. Even though World Vision Kenya has been involved in development projects in the area, there is still need for more targeted nutrition interventions by the organization.

Key Words

Under-fives, Nutritional status, Wasting, Stunting, Underweight

\section{FRENCH}

\section{RÉSUMÉ}

Une étude transversale a été menée dans la Division de Kathonzweni, District de Makueni, au Kenya, en vue d'évaluer et comparer l'état alimentaire d'enfants (qui ont entre 6 et 59 mois) pris de ménages participant à un projet de World Vision par rapport à une région en dehors de ce projet. Le but de l'étude était de fournir des données spécifiques à des régions sur la situation de la nutrition dans la région couverte par le projet de World Vision et établir s'il y a une différence significative par rapport à la zone non couverte par ce projet. Un total de 320 ménages, dont 160 étaient de la région couverte par le projet de World Vision, ayant chacun au moins un enfant âgé de 6-59 mois, ont été sélectionnés au hasard. Dans des ménages ayant plus d'un enfant se trouvant dans cette catégorie d'âge, un enfant seulement a été retenu pendant la sélection. Des questionnaires structurés ont été administrés aux mères ou à d'autres responsables d'enfants tandis que des mesures anthropométriques ont été prises pour tous les enfants dans les ménages faisant l'objet de l'étude. Le logiciel informatique Statistical package for Social Scientists (SPSS/PC $\left.{ }^{+}\right)$a été utilisé pour le stockage et l'analyse des données. Les indices de l'état alimentaire qui est mesuré par le poids par rapport à l'âge, la taille/hauteur par rapport à l'âge et le poids par 
rapport à la taille/hauteur étaient calculés en utilisant le programme Epi-Info. La fréquence du retard de croissance dans la région couverte par le projet (46.5\%) était légèrement plus élevée que dans la région non couverte par le projet (42.1\%). Un rapport significatif a été trouvé entre l'âge des enfants et leur état alimentaire en se basant sur la fréquence de la perte de poids et de la maigreur $(p<0.01)$ tandis que l'état alimentaire, basé sur le retard de croissance, était considérablement associé avec l'ordre de naissance. Dans l'ensemble, il n'y avait aucune différence significative dans la fréquence de retard de croissance, la perte de poids et la maigreur entre la région couverte par le projet de World Vision et la région non couverte par le projet. Cependant, la fréquence du retard de croissance et de la maigreur était plus élevée que les niveaux nationaux. Il est donc conclu que la malnutrition chronique est un problème dans la région étudiée et que l'âge est un facteur déterminant important. Bien que World Vision Kenya ait été impliqué dans des projets de développement dans cette région, il faut que cette organisation oriente ses interventions davantage sur la nutrition.

\section{Mots-clés}

Les enfants de moins de cinq ans, l'état de l'alimentation, la perte de poids, le retard de croissance, la maigreur.

\section{INTRODUCTION}

Child malnutrition is the most widely spread disorder in tropical and subtropical areas [1]. It is not a simple matter of whether one has satisfied one's appetite or not since a child who eats enough to satisfy immediate hunger can still be malnourished [2]. Malnutrition has been recognized as a consequence of poverty and is known to cause a great deal of both physical and emotional human suffering while it is viewed in the context of violation of child's human rights $[2,3]$.

Causes of malnutrition are complex, multidimensional and interrelated. In children, malnutrition is most likely to strike those who lack nutritionally adequate diets, are not protected from frequent illnesses and do not receive adequate care [2]. In Kenya, factors pertaining to shelter, women's workload and decision making opportunities, traditional beliefs and practices and men's attitude towards child care contribute to malnutrition and eventually to maternal and child deaths. At location and sub-location levels, lack of basic services, resource mobilization and administrative structures that are unresponsive to the community needs further aggravate the situation of malnutrition [4].

The nutritional status of infants and children under five years of age is of particular concern since the early years of life are crucial for optimal growth and development [5]. Their nutritional well-being reflects household, community and national investments in family health thereby contributing both directly and indirectly to overall country development and in particular, development of human resource [6]. It is reliably estimated that, globally 226 million children below 5 years old are stunted, 67 million are wasted and 183 million weigh less than they should for their age [2]. In Kenya, 33\% of the children under five years of age are chronically malnourished [6]. 
Community-based activities aimed at changing care practices and improving the nutritional status of children requires substantial resources in form of time and funds. Since this involves partnerships: communities, government, non-governmental organizations and other stakeholders have been involved in intervention projects within the marginalized semi-arid and arid areas of this country to maximize the quality of human life [7].

World Vision Kenya is one of the non-governmental organizations that are involved in various activities aimed at alleviating poverty through its 27 multi-sectoral projects called Area Development Programs (ADPs) in the drought prone districts such as Makueni, Wajir, Laikipia, Turkana and Marsabit [7]. Its activities include relief interventions, rehabilitation interventions, development of health institutions and health programmes, provision of safe water and shelter improvement. Other interventions by World Vision Kenya include: food security, micro enterprise development, vocational training and spiritual nurturing [7].

However, some of the Area Development programs (ADPs) such as Makueni ADP do not have focused data of the under-fives, yet these are some of the most important sets of data that help in the definition of health and nutritional status for purposes of programme planning, implementation and evaluation. These data are also key in directing programme resources to populations or communities with greatest health and/or nutritional need [8]. Information on social and economic characteristics of the households and the individual survey respondents which constitute the proxy indicators such as age, sex, education, environmental profile of households, childhood and infant mortality rates provide a context for the interpretation of demographic and health indices [6].

Out of this concern, a nutritional assessment to determine the nutritional status of children 659 months in the World Vision project area of Kathonzweni Division, Makueni district was conducted and compared with the non-project area to establish whether there is any significant difference in the nutritional status of children in the two groups.

\section{METHODOLOGY AND DESIGN}

\section{Study Area}

A comparative cross-sectional survey was carried out between August and September 2000 in Kathonzweni division of Makueni district. The division has 6 locations and 16 sub-locations, which cover an area of $880 \mathrm{~km}^{2}$. World Vision Kenya has activities in three locations namely: Mavindini, Kithuki and Kanzokea [9, 10]. Households within the Kanzokea locations, a World Vision project area and with children aged between 6-59 months were compared with those outside the project area but within the division (Thavu and Yeekanga sub-locations).

Rainfall pattern in the area is bimodal and generally scarce. It varies from $1000 \mathrm{~mm}$ to slightly below $500 \mathrm{~mm}$. The district falls within the Upper Midland 2 (UM2) agro-ecological zone and is characterized by sandy soil. Livestock farming is a major economic activity while crop farming is mainly for subsistence purposes $[9,10]$. 


\section{Sampling}

According to the Kenya Demographic Health Survey conducted in 1998, the proportion of children with chronic malnutrition (stunting) in Kenya is approximately 30\% [6]. This assumption and a confidence interval (CI) of 95\% were taken into account for sample size determination. Using the statistical formula for comparative studies, a sample size of 320 households was used and multi-stage sampling was done in the selection of households [11]. Makueni Area Development Programme (ADP) was purposively selected from the 27 ADPs of World Vision Kenya. In the Makueni ADP, simple random selection of the three community projects was done and Kanzokea project was selected covering Kimundi and a part of Yinthungu sub-location.

Random sampling of the non-project area, which had characteristics that were similar to the project area, was done after which Yeekanga and Thavu sub-locations were selected. A register of each set of households with children aged 6-59 months was developed and used as the sampling frame. Each household constituted a unit of analysis and had an equal probability of being included in the study. From the sampling frame, 160 households with children aged 6-59 months for each of the study area were systematically selected. This was achieved by first calculating the proportionate sample size for every village. From the list, every household with an even number was selected until the intended sample size was achieved.

\section{Data Collection}

A structured questionnaire was used in the study to collect information on socio-demographic and socio-economic characteristics of the households. A form in the structured questionnaire was used to record information on anthropometric measurements (weight, height and MidUpper-Arm Circumference $\{\mathrm{MUAC}\}$ ). The procedures followed in taking anthropometric measurements are as described by World Health Organization and United Nations [12,13]. Their corresponding deviation scores (Z-scores) were calculated with reference to the National Centre for Health Statistics (NCHS) population, using the cut-off points recommended by the World Health Organization [12].

The weight was recorded to the nearest $0.1 \mathrm{~kg}$. A measuring board with an accuracy of 0.1 $\mathrm{cm}$ was used to take the children's height. For those below two years, supine length was measured while for those above two years vertical height was taken. For MUAC, an arm circumference non-stretch tape graduated in centimetres and marked in appropriate colours (green, yellow and red) was used.

\section{Data analysis}

The data were entered and analysed using Statistical Package for Social Scientists (SPSS) version 10. To ensure that all the information had been correctly entered, frequencies for noncontinuous data and the mean values for continuous data were obtained before carrying out statistical analysis and used in checking for outliers. The Epi-Nut module in Epi-Info 
programme was used to convert raw anthropometric data (weight and height) into nutritional indicators (Weight-for-Age $\{\mathrm{WAZ}\}$, Height-for-Age $\{\mathrm{HAZ}\}$, and Weight-for-Height $\{\mathrm{WHZ}\}$ ) and compare them with the National Centre for Health Statistics (NCHS) reference figures.

Chi-square and t-test $(\mathrm{p}<0.05)$ were administered to compare the two groups. Confidence intervals were determined as applicable so as to indicate the precision of the study estimates as population values [14]. Two questionnaires were flagged off during conversion since their data were invalidated by the Epi-Nut programme that converts anthropometric values into indices of nutritional status, and were thus excluded from further analysis. Therefore, the analysis for nutritional status was done on 318 children. 


\section{RESULTS}

\section{Socio-Demographic and Socio-Economic Characteristics}

The total population in the 320 households was 2215 persons of which $50.9 \%$ were in the World Vision project area. Tests of statistical significance showed that the two groups were similar in the socio-economic and demographic characteristics (Table 1). The observed household size ranged from 2-15 persons.

The education levels of the population were essentially the same in both the project and nonproject areas. About a third in the study group were pre-school children (33.5\% and 33.4\%) in the project and non-project areas, respectively. Casual labour was found to be the major source of income for slightly more than half of the households in both the project area $(55 \%)$ and non-project area (58.8\%).

The prevalence of malnutrition by different indices of nutritional status based on height for age, weight for age, and weight for height is shown in Figure 1. They are represented using nutritional indicators stunting, underweight and wasting, respectively. There was no significant difference observed in the prevalence of chronic malnutrition manifested as stunting $(\mathrm{p}=0.500)$ and acute malnutrition manifested as wasting $(\mathrm{p}=0.332)$ in the two study areas.

The risk of being wasted was 1.6 times more likely to occur among children in the nonproject area compared to those in the project area $(\mathrm{p}=0.332, \mathrm{OR}=1.614, \mathrm{CI}=0.609-4.274)$. A higher percentage of children though not significantly different in the non-project area were underweight as compared to the project area. The risk of being underweight was 1.7 times more likely to occur in the non-project area compared to the project area $(p=0.527, \mathrm{OR}=$ $1.174, \mathrm{CI}=0.714-1.929)$.

Figure 1: Prevalence of malnutrition among children

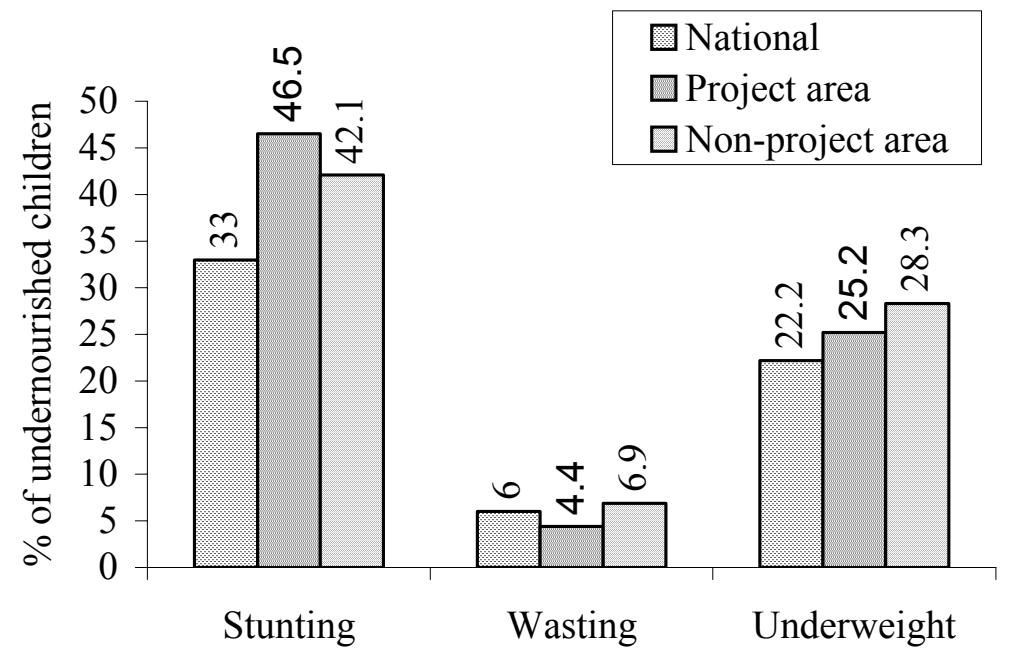

Nutritional indicator 
Using MUAC, results show that $7.8 \%$ of the children were below the -2 standard deviation as per the reference values by age-specific cut-off points. However, using a fixed cut-off point of $12.5 \mathrm{~cm}, 4.1 \%$ of the children were wasted with a higher but not statistically significant proportion in the non-project area (5\%) compared to the project area $(3.1 \%)$.

In the first year of life, stunting levels were observed to be characteristically low in both the project and non-project areas. The prevalence of wasting was found to be higher among children who had breastfed for less than 12 months in both areas (Table 2).

For the children who received other foods apart from breast milk within the first 3 months of life, the risk of being wasted was twice more likely to occur in the non-project area compared to the project area $(\mathrm{p}=0.259, \mathrm{OR}=2.43, \mathrm{CI}=0.498-11.823)$. Prevalence of severe stunting was observed in about half of the children who breastfed for less than 12 months in both the project area $(41.7 \%)$ and the non-project area (50\%). A decrease in prevalence of stunting was observed in both areas as the duration of breastfeeding increased.

A significant positive and linear relationship was found to exist between stunting and underweight and wasting and underweight after an inter-variable correlation analysis (Table 3). In both groups, there was a negative and significant relationship between the children's age and their nutritional status based on the level of underweight. Similar observation was made in relation to wasting and child's age. A significant positive relationship between childbirth order and stunting in the project area was observed.

\section{DISCUSSION}

The results of this study show that the prevalence of malnutrition in the community among the under-five-year-old children is high, which clearly confirms that malnutrition is a wide spread problem of public health significance. This is precipitated by many factors such as unfavourable breastfeeding practices, poor complementary feeding and health seeking practices, close birth spacing, low education levels and the general low socio-economic status. This is despite the fact that the World Vision Kenya is involved in the improvement of the factors through its activities in the area.

In general, prevalence of stunting was high but the prevalence of wasting was low in both areas as is usually found in non-emergency situations [15]. The stunting levels of children in both groups imply similar past nutritional experience. Stunting levels observed were higher than the levels reported in the 1998 demographic health survey for Eastern Province (36.8\%) in both groups and almost similar with those estimated by WHO for developing countries $(43 \%)[6,16]$. Stunting is generally associated with low socio-economic status, which is the case in both study groups [15].

The observation that the prevalence of stunting in the first year of life is low but increasing with age is similar to findings of a survey conducted in 2000 in Tharaka district [17]. This could be attributed to poor weaning and complementary feeding practices leading to an 
inadequate energy and protein intake. Similar findings of increase in stunting with age have been reported in Nigeria, and Samburu and Nyambene districts in Kenya [16,18,19].

Prevalence of severe wasting was higher in the non-project area (1.3\%) than the 1998 provincial figures of $0.9 \%$ for severe wasting [6]. Prevalence of underweight was also found to be higher in both areas than the national average of $22.2 \%$. The high prevalence of underweight and stunting is also similar with findings observed in a survey for drought prone districts of Kenya [20]. This implies that the situation in this area is worse than that of the average area in Kenya. This could be explained by the recurring drought situations in the district, which result in food shortages and thus inadequate dietary intake over a long period.

The positive significant relationship between childbirth order and prevalence of stunting could be explained by the fact that the family pot is shared among a large number of people in the household, thus inadequate dietary intake by children for a prolonged period and eventually the manifestation of chronic malnutrition. The negative significant relationship between wasting and child age indicates that cases of wasting are more prevalent with younger children. This could be explained by the fact that as a child grows older, he/she has access to different foods than a young infant who depends on only what is provided by the mother/caretaker, as observed by Meme [19].

High prevalence of malnutrition in children who breastfed for less than 12 months could be attributed to the fact that though breastfeeding stopped, the portions served as complementary foods may have been too little for the child. The children may also have been previously exposed to infections that could have resulted in reduced dietary intake, eventually leading to malnutrition. Severe cases of underweight and stunting were reported on children who were introduced to complementary foods after the age of six months in both areas. This could be attributed to inadequate dietary intake as well as reduced attention to the children with the arrival of a new baby.

\section{CONCLUSION}

From the findings of this study, it is concluded that chronic malnutrition among children in Kathonzweni division is a problem despite the community development support given by World Vision Kenya and age is an important factor in nutrition especially after the sixth month of life. Exclusive breastfeeding for the first six months and continued breastfeeding during the second year of life also appears to reduce the risk of stunting and wasting in children.

Therefore, a combined effort by the government, Non-governmental Organizations and the community at large is of ultimate importance in reducing the effects of drought and low economic status on the nutritional situation in this area. In addition, nutrition surveillance needs to be done continually and information about the nutritional status of the population gathered regularly to help in proper targeting and timely interventions for other future projects even by World Vision Kenya. 


\section{ACKNOWLEDGEMENTS}

We want to acknowledge the University of Nairobi and World Vision Kenya, which provided the funds that were used in this study.

\section{TABLES}

Table 1: Distribution of households by selected socio-demographic and economic characteristics in the project and non-project area

\begin{tabular}{|c|c|c|c|}
\hline \multirow[t]{2}{*}{ Characteristics } & Project area & Non-project area & Statistical \\
\hline & $\mathrm{N}=160$ & $N=160$ & Significance \\
\hline \multicolumn{4}{|c|}{ Population size and structure } \\
\hline Family size (average) & 7.0 & 6.8 & $\mathrm{NS}^{* *}$ \\
\hline Mean mothers age & $29.5(7.8)$ & $29.5(6.5)$ & $\mathrm{NS}^{* *}$ \\
\hline Mean fathers age & $36.9(9.9)$ & $35.6(8)$ & $\mathrm{NS}^{* *}$ \\
\hline Population & $\mathrm{n}=1099$ & $\mathrm{~N}=1073$ & \\
\hline$<15$ years $(\%)$ & 54.7 & 56.8 & NS* \\
\hline $15-64$ years $(\%)$ & 42.4 & 40.9 & NS* \\
\hline+64 years $(\%)$ & 2.9 & 2.3 & NS* \\
\hline \multicolumn{4}{|c|}{ Marital status of household head: } \\
\hline Married (\%) & 93.8 & 91.3 & NS* \\
\hline Single/widowed/ (\%) & 6.2 & 8.7 & NS* \\
\hline \multicolumn{4}{|l|}{ divorced/separated (\%) } \\
\hline
\end{tabular}

In brackets- Standard deviation $\quad$ NS - not significant at $\mathrm{p}$ value $<0.05$

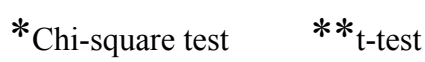


Table 2: $\quad$ Prevalence of malnutrition with age of complementary food introduction by study area

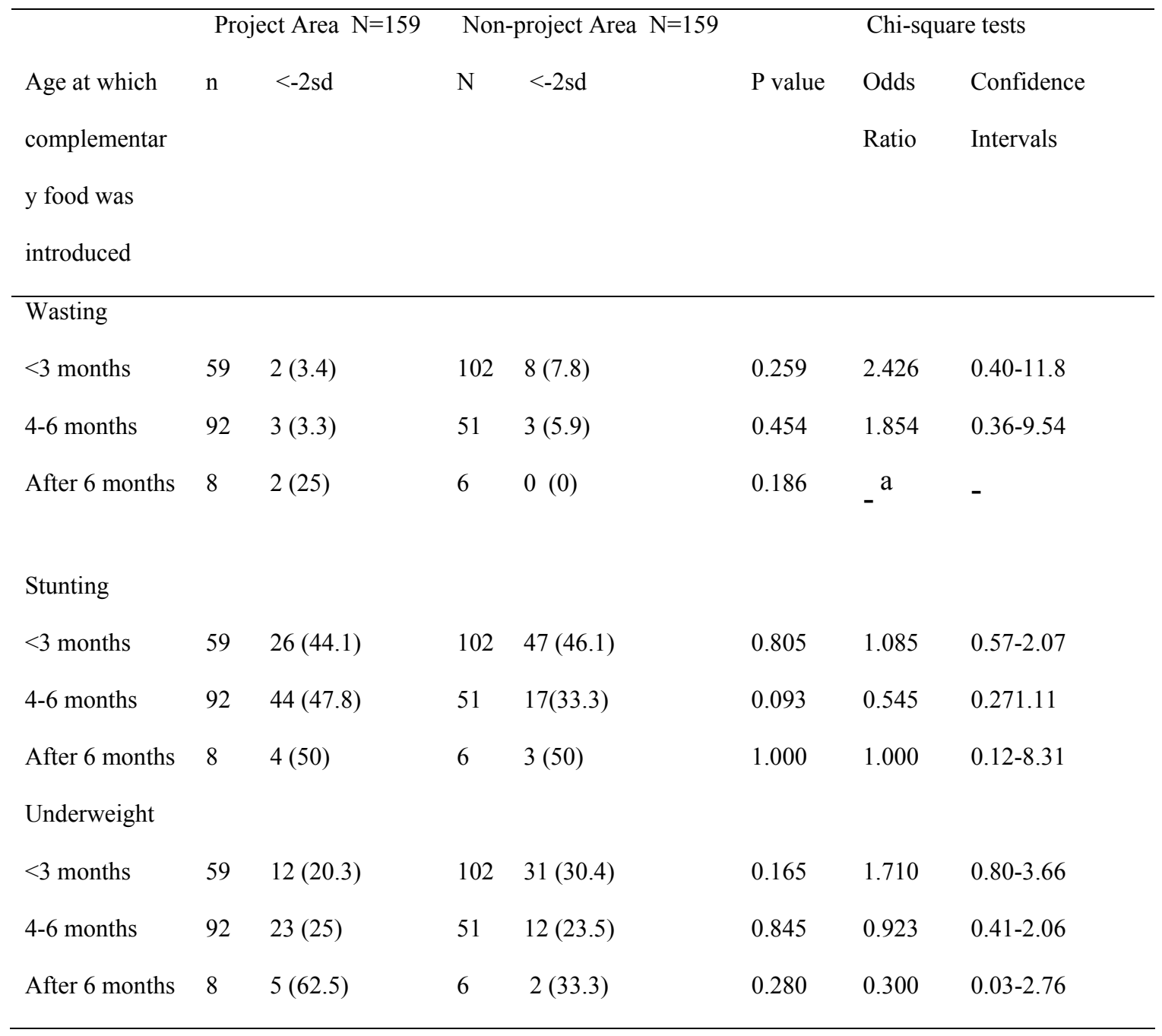

a

Could not be determined since the value in the non-project area is constant. Percentages (in parentheses) calculated within the particular category. 
Table 3: $\quad$ Pearson correlation coefficients for some variables with specific nutritional indicators for children in the project and non-project areas

\begin{tabular}{|c|c|c|c|c|c|c|}
\hline \multirow[t]{2}{*}{ Characteristics } & \multicolumn{3}{|c|}{ Project area } & \multicolumn{3}{|c|}{ Non-project area } \\
\hline & Stunting & Wasting & Underweight & Stunting & Wasting & Underweight \\
\hline Stunting & 1.000 & -0.089 & $0.645^{* *}$ & 1.000 & -0.020 & $0.711^{* *}$ \\
\hline Wasting & $-0.189^{*}$ & 1.000 & $0.608 * *$ & -0.020 & 1.000 & $0.675 * *$ \\
\hline Underweight & $0.645 * *$ & $0.608 * *$ & 1.000 & $0.711 * *$ & $0.675 * *$ & 1.000 \\
\hline Child age & 0.044 & $-0.356 * *$ & $-0.189^{*}$ & -0.032 & $-0.281 * *$ & $-0.211^{* *}$ \\
\hline Childbirth order & $0.159^{*}$ & -0.057 & $-0.156^{*}$ & -0.131 & -0.034 & -0.069 \\
\hline Protein amount & -0.120 & 0.016 & -0.111 & -0.165 & -0.082 & -0.168 \\
\hline Caloric amount & -0.101 & 0.016 & -0.144 & -0.217 & 0.092 & -0.120 \\
\hline
\end{tabular}

**-Significant at 0.01 level (2-tailed test) *- Significant at 0.05 level (2-tailed test) 


\section{REFERENCES}

1. Jansen A and KO Bailey The Early Detection of Childhood Malnutrition in South Pacific. Geneva, Switzerland 1972: 1-2.

2. UNICEF. The Situation Analysis of Children and Women in Kenya, Nairobi. Ministry of Planning and National Development and UNICEF, Kenya Country Office 1998: 11-195.

3. Smith LC and L Haddad Explaining Child Malnutrition in Developing Countries. A Cross-country Analysis-Research Report (III). IFPRI. Washington DC 2000: 1-4.

4. UNICEF. The Situation Analysis of Children and Women in Kenya ${ }_{2}$ Nairobi. Ministry of Planning and National Development and UNICEF, Kenya Country Office 1992: 1-92.

5. Prechulek H, Aldana JM and $\mathbf{N}$ Hasan Feeding Practices and Malnutrition in Children in Rural Bangladesh. Food and Nutr. Bull. 1999; 20 (4): 396-400.

6. Central Bureau of Statistics. Kenya Demographic and Health Survey, 1998. National Council for Population and Development, Ministry of Planning and National Development, Nairobi Kenya. Macro International Inc. Calverton, Maryland USA 1999: 9-124.

7. Maingi C World Vision Kenya Silver Jubilee Brochure. World Vision Kenya Communication Department. Nairobi 1999: 3-10.

8. WHO. Physical Status: The Use and Interpretation of Anthropometry. Technical report series 854. Geneva 1995.

9. GoK. Makueni District Development Plan 1994-1996. Office of the Vice President and Ministry of Planning and National Development. Nairobi 1994:117.

10. GoK. Makueni District Development Plan 1997-2001. Office of the Vice President and Ministry of Planning and National Development. Nairobi 1997 :343.

11. Fisher AA, Laing JA and JW Townsend Handbook for Family Planning Operations Research, $2^{\text {nd }}$ ed. Population Council. New York, USA 1991: 40-46.

12. WHO. Measuring Change in Nutritional Status: Guidelines for Assessing the Nutritional Impact of Supplementary Feeding Programmes for Vulnerable Groups. Geneva 1983: 12-14.

13. UNITED NATIONS. How to Weigh and Measure Children: Assessing the Nutritional Status of Children in Household Surveys. Department of Technical Cooperation for Development and Statistical office. New York, USA 1986: 6-65.

14. Norman GR and DL Streine PDQ Statistics. BC Decker Inc. Philadelphia, Pennsylvania 1986: 27-45. 
15. Jooste PL, Langenhoven ML, Kriek JA, Kunneke E, Nyaphusi $M$ and B Sharp Nutritional Status of Rural Children in the Lesotho Highlands. E Afr Med J. 1997; 74 (11): 680-688.

16. Zoakah AI, Idoko LO, Okoronkwo MO and OA Adeleke Prevalence of Malnutrition Using Z-scores and Absolute Values in Children Under Five Years of Age in Utan Village, Jos, Plateau State, Nigeria. E Afr Med J. 2000; 77 (3): 123-126.

17. ANP. Food and Nutrition Security Survey in Maragua and Gikingo Locations of Tharaka District, Eastern Province, Kenya. Applied Nutrition Programme, Department of Food Science Technology and Nutrition, University of Nairobi 2000:17-45.

18. Kielmann AA, Ehrlich AS, Jansen AAJ, Kielmann N, Kinyingi DM, Maina GW, Maritim GK, Mutuga JN and DN Njama Assessment of the Nutritional Impact of the Wamba Food Security Programme. Unit of Applied Human Nutrition, Department of Food Science, Technology and Nutrition, University of Nairobi. 1988:31-36.

19. Meme MM Nutrient Intake and Nutritional Status of Primary School Children in a School With and Without a Feeding Programme in Nyambene District, Kenya. MSc Thesis, University of Nairobi 1996: 48-71

20. Kogi-Makau W, Muroki NM and A Omwega A Rapid Food and Nutritional Assessment in Six Drought Prone Districts in Kenya, Socio-economic Characteristics of Households and Nutritional Status of Children. ANP/ANAPH, Department of Food Science, Technology and Nutrition, University of Nairobi. 2000: 63-65. 